\title{
Predictors of mortality following emergency open colectomy for ischemic colitis: a single-center experience
}

\author{
Nassiba Beghdadi ${ }^{1 \dagger}$, Elisa Reitano ${ }^{1 \dagger}$, Frederic Cochennec ${ }^{2}$, Pascal Desgranges ${ }^{2}$, Aurelien Amiot $^{3}$, Iradj Sobhani ${ }^{3}$, \\ Nicolas Mongardon ${ }^{4,5}$, Olivier Langeron ${ }^{4,5}$, Margherita Notarnicola', Sébastien Mulée, ${ }^{6,7}$, Alain Luciani ${ }^{6,7}$, \\ Florence Canoui-Poitrine ${ }^{8}$, Alexis Laurent ${ }^{1}$, Daniele Sommacale ${ }^{1}$, Francesco Brunetti ${ }^{1}$ and Nicola de Angelis $^{1 *}$ (D)
}

\begin{abstract}
Background: Ischemic colitis (IC) is a severe emergency in gastrointestinal surgery. The aim of the present study was to identify the predictors of postoperative mortality after emergent open colectomy for IC treatment. Additionally, we compared postoperative outcomes of patients undergoing emergent colectomy due to aortic surgery-related IC (AS-IC group) vs. other IC etiologies (Other-IC group).
\end{abstract}

Methods: We analyzed records of consecutive patients who underwent emergency open colectomy for IC between 2008 and 2019. Logistic regression analysis was performed to identify clinical and operative parameters associated with postoperative mortality. The AS-IC and Other-IC groups were compared for mortality, morbidity, ICU stay, hospital stay, and survival.

Results: During the study period, 94 patients (mean age, $67.4 \pm 13.7$ years) underwent emergent open colectomy for IC. In the majority of cases, IC involved the entire colon (53.2\%) and vasopressor agents were required preoperatively (63.8\%) and/or intraoperatively (78.8\%). Thirty-four patients underwent surgery due to AS-IC, whereas 60 due to Other-IC causes. In the AS-IC group, 9 patients had undergone endovascular aortic repair and 25 open aortic surgery; 61.8\% of patients needed aortic surgery for ruptured abdominal aortic aneurism (AAA). Overall, 66 patients (70.2\%) died within 90 days from surgery. The AS-IC and Other-IC groups showed similar operative outcomes and postoperative complication rates. However, the duration of the ICU stay (19 days vs. 11 days; $p=0.003$ ) and of the total hospital stay (22 days vs. 16 days; $p=0.016$ ) was significantly longer for the AS-IC group than for the Other-IC group. The rate of intestinal continuity restoration at 1 year after surgery was higher for the Other-IC group than for the AS-IC group (58.8\% vs. 22.2\%; $p=0.05)$. In the multivariate model, preoperative increased lactate levels, a delay between signs/symptoms' onset and surgery $>12 \mathrm{~h}$, and the occurrence of postoperative acute kidney injury were statistically associated with postoperative mortality. Neither IC etiology (aortic surgery vs. other etiology) nor ruptured AAA was associated with postoperative mortality.

Conclusion: Emergency open colectomy for IC is associated with high postoperative mortality, which appears to be unrelated to the IC etiology. Preoperative lactate levels, > 12-h delay to surgery, and postoperative acute kidney injury are independent predictors of postoperative mortality.

Keywords: Ischemic colitis, Abdominal surgery, Emergency surgery, Aortic surgery

\footnotetext{
* Correspondence: nic.deangelis@yahoo.it

${ }^{\dagger}$ Nassiba Beghdadi and Elisa Reitano contributed equally to this work.

'Unit of Digestive and HPB surgery, CARE Department, Henri Mondor

Hospital, AP-HP, and Université Paris Est, UPEC, 51 Avenue du Maréchal de Lattre de Tassigny, 94010 Créteil, France

Full list of author information is available at the end of the article
}

\section{$\triangle B M C$}

(c) The Author(s). 2020 Open Access This article is licensed under a Creative Commons Attribution 4.0 International License, which permits use, sharing, adaptation, distribution and reproduction in any medium or format, as long as you give appropriate credit to the original author(s) and the source, provide a link to the Creative Commons licence, and indicate if changes were made. The images or other third party material in this article are included in the article's Creative Commons licence, unless indicated otherwise in a credit line to the material. If material is not included in the article's Creative Commons licence and your intended use is not permitted by statutory regulation or exceeds the permitted use, you will need to obtain permission directly from the copyright holder. To view a copy of this licence, visit http://creativecommons.org/licenses/by/4.0/ The Creative Commons Public Domain Dedication waiver (http://creativecommons.org/publicdomain/zero/1.0/) applies to the data made available in this article, unless otherwise stated in a credit line to the data. 


\section{Introduction}

Ischemic colitis (IC) is a severe emergency in gastrointestinal surgery [1], being associated with mortality rates of $50-80 \%[2,3]$. IC represents the most common type of intestinal ischemia with an estimated incidence of 15.6$17.7 / 100,000$ person-years [4]. Recognized risk factors for IC are arterial hypertension, coronary artery disease, peripheral vascular disease, atrial fibrillation, diabetes mellitus, chronic kidney diseases, and hemodialysis [5-8]. Once diagnosed, adverse prognostic factors for IC-related mortality include age > 50 years [5], hemodynamic instability [5], isolated right colon involvement [7, 9], history of hypertension, and chronic kidney diseases [7, 8].

The etiologies of IC are numerous, but they can be divided into two main categories: occlusive and nonocclusive diseases [4]. In both cases, IC is the result of blood supply insufficiency to the colon leading to various severities of ischemic lesions, from superficial mucosal lesions to full-thickness transmural necrosis [10]. The clinical presentation is related to the severity and extent of the ischemia lesions. The most frequent symptoms are abdominal pain, diarrhea, mild lower gastrointestinal bleeding, and elevated or persistent fever $[4,11,12]$.

$\mathrm{IC}$ is considered as one of the most severe postoperative complications of aortic surgery, occurring in $2 \%$ of patients operated on in an elective setting and in 9\% of patients operated on in emergency $[13,14]$. IC occurring after aortic surgery has been reported to increase mortality by $50 \%$ [15]. Several studies investigated the risk factors of IC after abdominal aneurysm (AAA) repair and compared the occurrence of IC after endovascular aortic repair (EVAR) vs. open aneurysm repair [16-19]. Older age, female gender, ruptured aneurysm, emergency surgery, prolonged surgery, aortic clamping duration, and previous cardiovascular history were associated with an increased risk of IC [5, 15, 17, 20, 21]. On the contrary, EVAR surgery was found to be protective towards IC compared to open aortic surgery probably due to lower ischemia-reperfusion injury and peripheral proinflammatory cytokine release $[16,22,23]$.

Depending on the severity and IC grade, two treatment strategies can be discussed: a conservative approach or a surgical treatment $[24,25]$. IC patients who require surgical treatment are most of the time operated on in an emergency setting, which is associated with a higher risk of postoperative mortality than elective surgery [14, 26, 27].

The aim of the present study was to identify predictors of postoperative mortality in patients requiring emergency open colectomy for IC treatment. Additionally, we compared postoperative outcomes of patients undergoing emergency colectomy due to aortic surgery-related IC vs. other IC etiologies.

\section{Methods}

We scrutinized records of consecutive patients who underwent emergency open colectomy for IC at the
Henri Mondor University Hospital of Creteil (France) between January 2008 and February 2019. The study protocol was approved by the Institutional Review Board (IRB: 00011558) and was conducted in conformity to the principles declared to the National Commission for Data Protection and Liberties (CNIL: 2210699) and in accordance with the ethical principles described in the Declaration of Helsinki.

\section{Study population}

To be included in the present analyses, IC patients should have been treated with an emergency open colectomy; IC diagnosis should have been confirmed preoperatively by computed tomography scan and colonoscopy and then by histology on the surgical specimen. At the contrastenhancement computed tomography scan, IC was identified as large bowel wall thinning ("paper-thin-wall"), or any large bowel wall thickening and/or abnormal wall enhancement. Porto-mesenteric venous gas, pneumatosis, free intraperitoneal air, and mesenteric arterial or venous thrombus may also be present $[5,13,28,29]$. Colonoscopy findings were classified according to Favier's classification [30].

According to the IC etiology, patients were divided into 2 groups: those with aorta surgery-related IC (AS-IC group) and those with IC of other etiologies (Other-IC group). IC in the AS-IC group should have occurred during the aorta surgery hospitalization. We collected baseline characteristics including demographics, comorbidities, IC etiologies and location, and the need of preoperative vasopressor agents (norepinephrine/epinephrine). We estimated the Ischemic Colitis Mortality Risk (ICMR) score as described by Reissfelder et al. [31]. Operative and postoperative variables were also retrieved and compared between the groups.

\section{Emergency open colectomy procedure}

The extent of the colonic resection depended on the severity of IC, based on preoperative and intraoperative findings, varying from segmental to total colectomies. After a midline laparotomy, the peritoneal cavity was explored. All necrotic, thickened, or edematous colonic segments were resected. The colon was transected in a macroscopically healthy area identified by the operating surgeon. For a left colon lesion, a Hartmann resection or a left colectomy, including the resection of the rectosigmoid junction, was performed. For IC located on the right colon, a right colectomy with resection of the right flexure and a double-barreled ileo-colostomy were performed. For ischemic lesions involving the right colon up to the splenic flexure, a subtotal colectomy was performed. For pancolic ischemia, a total colectomy with terminal ileostomy was performed. After surgery, all patients were admitted to the intensive care unit (ICU). 


\section{Study outcomes}

The main study outcome was postoperative mortality, defined as in-hospital mortality or within 90 days from colonic resection. Secondary outcomes included intraoperative variables, postoperative morbidity, and ICU stay and hospital stay duration. The hospital stay duration was counted starting from the day of the emergency colectomy for IC. Acute kidney injury was defined according to the KDIGO classification [32]. Myocardial infarction was defined as isolated troponin elevation, electrocardiogram changes, and/or clinical evidence of heart attack. Respiratory complications were defined as postoperative occurrence of pneumonia or need for prolonged intubation (> $48 \mathrm{~h}$ ). Severity of postoperative complications was categorized by using the Clavien-Dindo Classification [33]. Survivors were followed up; during the first year, restoration of intestinal continuity was performed if suitable.

\section{Statistical analysis}

Statistics were performed with tee SPSS software (Statistical Package for Social Science, IBM SPSS Statistics, version 23 for Macintosh; IBM Corp., Armonk, NY, USA). Continuous variables are expressed as mean (SD) or median (range), as appropriate. Categorical variables are expressed as frequency $(n, \%)$. Student $t$ test, MannWhitney $U$ test, Fisher exact test, or chi-square test was used for group comparisons, as appropriate. Logistic regression analysis was performed to identify clinical and operative parameters associated with postoperative mortality including the model variables that reached a $p$ value $<0.2$ at the univariate analysis. Odds ratios (OR) and adjusted OR (AOR) are presented with $95 \%$ confidence interval $(\mathrm{CI})$. A $p$ value $\leq 0.05$ was considered as statistically significant.

\section{Results}

During the study period, 94 patients underwent emergency open colectomy for IC. The study population had a mean age of $67.4 \pm 13.7$ years, with $65.9 \%$ being women. In the majority of cases, IC involved the entire colon (53.2\%), requiring a total colectomy with terminal ileostomy. The time interval from signs/symptoms onset to surgery was $>12 \mathrm{~h}$ in $75.5 \%$ of patients. The majority of patients needed vasopressors preoperatively (63.8\%) and/or intraoperatively (78.8\%) (Table 1).

Concerning the cause of IC, 34 patients (36.2\%) presented with an AS-IC and 60 patients (63.8\%) with an Other-IC. In the AS-IC group, 9 patients had undergone EVAR, and 25 open aortic surgery; overall, 21/34 patients $(61.8 \%)$ needed aortic surgery for AAA rupture. The Other-IC causes included occlusive diseases (e.g., trauma (4), arterial emboli (4), radiation (3), thrombosis emboli (2)) and non-occlusive diseases (e.g., colon cancer (2), cocaine abuse (1); Clostridium difficile (2), inflammatory bowel disease (3), non-steroidal anti- inflammatory drugs (5), volvulus (5), hemodialysis (5), hypo-perfusion (10)). The median follow-up period was 36 months (range, 9-60 months).

Operative and postoperative outcomes for the entire study populations are summarized in Table 2. Overall, 66 patients $(70.2 \%)$ died within 90 days from surgery.

\section{Comparison of AS-IC vs. Other-IC patients}

The clinical characteristics of patients in the AS-IC vs. Other-IC group are presented in Table 3. Significant between-group differences were found only for the prevalence of hypertension, the location of ischemia and consequently the extent of colonic resection, and the use of open abdomen. Comparisons between the AS-IC group and Other-IC group for postoperative outcomes are presented in Table 4. After adjustment on the demographic and clinical variables that were significantly different between the AS-IC and Other-IC groups, the two groups showed similar rates of postoperative multiorgan failure, acute kidney injury, respiratory failure, and postoperative mortality (Table 4). However, the ICU stay (19 days vs. 11 days; $p=0.003$ ) and the total hospital stay durations (22 days vs. 16 days; $p=0.016$ ) were significantly longer for the AS-IC group than for the Other-IC group. The rate of restoration of the intestinal continuity at 1 year was higher in the Other-IC group than in the AS-IC group (58.8\% vs. $22.2 \% ; p=0.05$ ) (Table 4 ).

\section{Predictors of postoperative mortality}

At the univariate analysis, lactate level $>2.5 \mathrm{mmol} / \mathrm{L}$, time from signs/symptoms' onset to surgery $>12 \mathrm{~h}$, need of preoperative and/or intraoperative adrenergic vasopressors, sepsis, and blood loss $>500 \mathrm{~mL}$ were found to be significantly associated with postoperative mortality (Table 5). In the multivariate model, preoperative lactate levels, time from signs/symptoms onset to surgery, and postoperative acute kidney injury were statistically associated with the occurrence of postoperative mortality. The presence of AAA rupture and the IC etiology (aortic surgery vs. other etiology) were not significantly associated with postoperative mortality (Table 5 ).

\section{Discussion}

The present single-center study showed that IC requiring an emergency open colectomy is associated with a high postoperative mortality, which can be predicted by high levels of preoperative lactates, delayed interval from signs/symptoms onset to surgery ( $>12 \mathrm{~h}$ ), and the occurrence of postoperative acute kidney injury. On the contrary, the specific etiology of IC does not impact on the outcome.

Prediction of postoperative outcomes and risk assessment can be of particular importance facing a pathology that requires an optimized emergency management. In 
Table 1 Summary of the clinical characteristics of patients undergoing emergent colectomy for ischemic colitis $(n=94)$

\begin{tabular}{|c|c|}
\hline Variables & Whole sample \\
\hline Gender (F/M) $[n]$ & $62 / 32$ \\
\hline Age, years [mean (SD)] & $67.44(13.70)$ \\
\hline Age $>75$ years $[n(\%)]$ & $34(36.2)$ \\
\hline BMI $\left(\mathrm{kg} / \mathrm{m}^{2}\right)[$ mean $(\mathrm{SD})]$ & $23.25(4.98)$ \\
\hline $\mathrm{BMI}>30\left(\mathrm{~kg} / \mathrm{m}^{2}\right)[n(\%)]$ & $11(11.7)$ \\
\hline Preoperative leukocytes $\left(10^{9} / \mathrm{L}\right)[$ mean $(\mathrm{SD})]$ & $14.51(9.69)$ \\
\hline Preoperative hemoglobin (g/L) [mean (SD)] & $10.33(2.71)$ \\
\hline Preoperative creatinine (mg/dL) [mean (SD)] & $195.55(142.09)$ \\
\hline Preoperative lactates (mg/dL) [mean (SD)] & $5.4(4.31)$ \\
\hline Preoperative pH [mean (SD)] & $7.25(0.15)$ \\
\hline Protrombin ratio (\% of normal) [mean (SD)] & $73(15.36)$ \\
\hline Diabetes $[n(\%)]$ & $16(17)$ \\
\hline Severe coronary disease $[n(\%)]$ & $70(74.5)$ \\
\hline Previous TIA/stroke [n (\%)] & $8(8.5)$ \\
\hline Hypertension [n (\%)] & $66(70.2)$ \\
\hline COPD $[n(\%)]$ & $20(21.3)$ \\
\hline Smoking $[n(\%)]$ & $30(31.9)$ \\
\hline Kidney failure $[n(\%)]$ & $24(25.5)$ \\
\hline Previous carotid surgery [n (\%)] & $6(6.4)$ \\
\hline Previous aortic stenting $[n(\%)]$ & $14(14.9)$ \\
\hline Previous legs vascular surgery [n (\%)] & $12(12.8)$ \\
\hline Previous colectomy [n (\%)] & $2(2.1)$ \\
\hline Comorbidity $>1[n(\%)]$ & $42(44.7)$ \\
\hline Cardioasa therapy $[n(\%)]$ & $19(20.2)$ \\
\hline Oral anticoagulant therapy $[n(\%)]$ & $24(25.5)$ \\
\hline Charlson Index [mean (SD)] & $5.41(2.69)$ \\
\hline \multicolumn{2}{|l|}{ ASA Score $[n(\%)]$} \\
\hline$\|$ & $10(10.6)$ \\
\hline III & $58(61.7)$ \\
\hline IV & $26(27.7)$ \\
\hline \multicolumn{2}{|c|}{ Time interval from signs/symptoms onset to surgery [n (\%)] } \\
\hline$<=12 \mathrm{~h}$ & $23(24.5)$ \\
\hline$>12 h$ & $71(75.5)$ \\
\hline \multicolumn{2}{|l|}{ Localization of ischemia [n (\%)] } \\
\hline Left colon & $19(20.2)$ \\
\hline Right colon & $4(4.3)$ \\
\hline Transverse & $6(6.4)$ \\
\hline Right and transverse & $15(16)$ \\
\hline Entire colon & $50(53.2)$ \\
\hline \multicolumn{2}{|l|}{ Etiology of ischemia [n (\%)] } \\
\hline Aortic surgery & $34(36.2)$ \\
\hline Open surgery & 25 \\
\hline EVAR & 9 \\
\hline Other etiologies & $60(63.8)$ \\
\hline
\end{tabular}


Table 1 Summary of the clinical characteristics of patients undergoing emergent colectomy for ischemic colitis ( $n=94)$ (Continued)

\begin{tabular}{ll}
\hline Variables & Whole sample \\
\hline Presence of colic perforation $[n(\%)]$ & $20(21.3)$ \\
Presence of aneurysmatic rupture $[n(\%)]^{\mathrm{a}}$ & $21(61.8)$ \\
Type of colonic resection $[n(\%)]$ & $19(20.2)$ \\
$\quad$ Hartman's resection & $21(22.3)$ \\
$\quad$ Subtotal colectomy with ileo-sigmoid colostomy & 50 (53.2) \\
$\quad$ Total colectomy with terminal ileostomy & $4(4.3)$ \\
$\quad$ Right colectomy with ileo-colonostomy & $4(4.3)$ \\
Open abdomen needed $[n(\%)]$ & $60(63.8)$ \\
Preoperative vasopressor agents $[n(\%)]$ & $74(78.8)$
\end{tabular}

ASA American Society of Anesthesiologist classification, BMI body mass index, COPD chronic obstructive pulmonary disease, IC ischemic colitis TIA transient ischemic attack

${ }^{\mathrm{a}}$ Regarding patients with AS etiology

this perspective, some authors proposed different predictive scores aiming at guiding the clinical treatment choice and anticipating postoperative complications after colonic resection for IC [5, 34, 35].

In 2010, Chung et al. [35] proposed a prognostic model able to accurately identify severe IC requiring surgery or life-threatening based on 3 preoperative variables: tachycardia, shock within $24 \mathrm{~h}$ after admission, and endoscopic evidence of ulceration. The probability of severe IC was $1 \%$ if none of these 3 variables was present and was $74 \%$ if the 3 components were all present [35]. This score is of interest to assess the patient's risk once IC is diagnosed and prior to surgery. By providing a method to assess a patient's prognosis, it guides clinicians in the choice of the best management strategy and postoperative protocol, which must take into account the individual patient's risk.

In 2011, Reissfelder et al. [31] developed the ICMR score, a risk score to predict perioperative mortality in patients undergoing surgery for IC. In 2013, Castleberry et al. [34] assessed the validity of the ICMR score in their 10-year cohort composed of 115 patients who underwent colectomy for acute IC. They reported an adequate discriminatory accuracy in predicting in-hospital mortality with an area under the receiver operating characteristic curve of 0.75 . When analyzed separately, the individual components of the ICMR score that performed better were the preoperative lactate levels $>2.5$ $\mathrm{mmol} / \mathrm{L}$, the occurrence of postoperative kidney injury requiring hemodialysis, and the use of intraoperative vasopressor. On the contrary, the non-occlusive etiology of IC and the need of total/subtotal colectomy were not significantly associated with in-hospital mortality [34].

In accordance with the previous literature (Table 6), the present study confirms the predictive value of the preoperative lactate levels and the occurrence of postoperative acute kidney injury, whereas the need of intraoperatory adrenergic vasopressors and the ICRM score showed only a statistical trend. We also observed that the delay to surgery can significantly impact on the risk of in-hospital mortality, being those operated on after $>12 \mathrm{~h}$ from signs/symptom onset drastically more at risk than those receiving an early diagnosis and a prompt surgical treatment.

The definition of immediate and delayed surgery varies among the studies $[8,20,31,36,37]$. In some studies, as in the present one, immediate surgery was defined as the surgical treatment performed within $12 \mathrm{~h}$ from admission or surgical consultation, whereas delayed surgery as the intervention performed more than $12 \mathrm{~h}$ after admission owing to severe or worsening clinical conditions, or no response to conservative therapy [8]. As known, the clinical presentation of IC can be vague and unspecific, and the frequent presence of pre-existing medical conditions may hamper a timely diagnosis [4, 26, 38]. Severe cases at presentation have more chance to be rapidly taken in the operating room, but they are also associated with poorer outcomes due to the severity and extent of the ischemic lesion $[4,5,8,15,26,31,36,39]$. When comparing mortality rates after emergency colectomy for IC, it is thus important to take into account the type of procedure performed (e.g., segmental resection, total colectomy), the surgical setting (e.g., emergency or delayed surgery), and the patient's status (e.g., comorbidities, hemodynamic stability). Some authors advocated for an aggressive approach with extended colonic resections (e.g., left colectomy or subtotal colectomy) and only rarely limited to a segment (e.g., right colectomy) $[3,10,13]$. Indeed, acute IC located in the right colon should be considered as an extended colonic hypoperfusion with global hypo-perfusion in the mesenteric superior artery territory. However, an aggressive management is not supported by all surgeons. Paterno et al. [8] suggested that in case of limited IC extension and no hemodynamic instability, a segmental colon resection is 
Table 2 Summary of operative and postoperative characteristics of patients undergoing emergent colectomy for ischemic colitis

\begin{tabular}{|c|c|}
\hline Variables & Whole sample \\
\hline Operative time, min [mean (SD)] & $151.54(55.33)$ \\
\hline Estimated blood loss, mL [median (range)] & $450(100-890)$ \\
\hline Transfused patients [n (\%)] & $50(53.2)$ \\
\hline Postoperative multi-organ failure $[n(\%)]$ & $56(59.6)$ \\
\hline Postoperative acute kidney injury [n (\%)] & $51(54.3)$ \\
\hline Postoperative liver failure $[n(\%)]$ & $5(5.3)$ \\
\hline Postoperative heart attack [n(\%)] & $8(8.5)$ \\
\hline Postoperative stroke $[n(\%)]$ & $2(2.1)$ \\
\hline Postoperative metabolic acidosis [ $(\%)]$ & $1(1.1)$ \\
\hline Postoperative respiratory failure $[n(\%)]$ & $17(18.1)$ \\
\hline Postoperative low output syndrome $[n(\%)]$ & $5(5.3)$ \\
\hline Postoperative sepsis $[n(\%)]$ & $38(40.4)$ \\
\hline \multicolumn{2}{|l|}{ Postoperative complication severity (Clavien-Dindo Classification) [n (\%)] } \\
\hline III/IV & $28(29.8)$ \\
\hline V & $66(70.2)$ \\
\hline Patients in ICU $[n(\%)]$ & $94(100)$ \\
\hline Duration of ICU stay, days [mean (SD)] & $14.50(17.17)$ \\
\hline Reoperation during the same admission $[n(\%)]$ & $18(19.1)$ \\
\hline Hospital stay, days [mean (SD)] & $18.26(20.85)$ \\
\hline Postoperative mortality at 90 days $[n(\%)]$ & $66(70.2)$ \\
\hline Survival at 1 year [n(\%)] & $26(27.6)$ \\
\hline \multicolumn{2}{|l|}{ Disposition* $[n(\%)]$} \\
\hline Home & $11(39.3)$ \\
\hline Rehabilitation hospital/elderly house & $17(60.7)$ \\
\hline Restoration of intestinal continuity at 1 year after surgery ${ }^{* *}[n(\%)]$ & $12(46.1)$ \\
\hline Mortality after restoration of intestinal continuity at 1 year after surgery $[n(\%)]$ & 0 \\
\hline \multicolumn{2}{|l|}{ Survival status at the last follow-up visit* } \\
\hline Alive & $22(75.9)$ \\
\hline Dead for IC-related causes & $3(10.3)$ \\
\hline Dead for other causes & $3(10.3)$ \\
\hline
\end{tabular}

ICU intensive care unit

${ }^{*} n=28$

$* * n=26$

an effective option, without increased mortality. In the present study, we considered a sample of IC patients all requiring emergency surgery; in $53.2 \%$ of cases, IC involved the entire colon. The colonic resection was adapted to the IC extension, leading to a great majority of subtotal or total colectomies.

Previous studies reported high mortality rates for IC developed after ruptured AAA repair surgery $[15,16,20,26,40]$, with some differences related to the type of aortic surgery $[14,22,40]$. Indeed, a recent systematic review and metaanalysis demonstrated that IC occurs more frequently after open repair (2.1-3.6\%) than in EVAR (0.5-1\%) in the elective setting [22]. However, once IC occurred and an emergency colectomy is required, the mortality appears to be independent of the type of aortic surgery performed. The present study confirms these findings and suggests that there is no evidence of an impact on mortality of the specific IC etiology, namely the aortic surgery-related cause or other causes, including occlusive and non-occlusive diseases.

In the present study, survivors of open colectomy underwent a restoration of the intestinal continuity in almost $50 \%$ of cases, with no related postoperative mortality. Interestingly, the rate of intestinal continuity restoration within 1 year from surgery was higher for patients in the Other-IC group than in the AS-IC one. This difference may be explained by several factors, such as 
Table 3 Summary of the clinical characteristics of IC patients undergoing emergency open colectomy due to aorta surgery-related IC (AS-IC group) vs. other etiologies (Other-IC group)

\begin{tabular}{|c|c|c|c|}
\hline Variables & AS-IC group $(n=34)$ & Other-IC group $(n=60)$ & $p$ value \\
\hline Gender (F/M) $[n]$ & $9 / 25$ & $23 / 37$ & 0.267 \\
\hline Age, years [mean $(\mathrm{SD})]$ & $69.74(10.73)$ & $66.13(15.05)$ & 0.223 \\
\hline Age > 75 years $[n(\%)]$ & $14(41.2)$ & $20(33.3)$ & 0.506 \\
\hline BMI $\left(\mathrm{kg} / \mathrm{m}^{2}\right)$ [mean (SD)] & $22.8(4.92)$ & $23.46(5.05)$ & 0.634 \\
\hline $\mathrm{BMI}>30\left(\mathrm{~kg} / \mathrm{m}^{2}\right)[n(\%)]$ & $4(11.8)$ & $7(11.7)$ & 1 \\
\hline Preoperative leukocytes $\left(10^{9} / \mathrm{L}\right)$ [mean $\left.(\mathrm{SD})\right]$ & $11.94(8.18)$ & $15.90(10.22)$ & 0.062 \\
\hline Preoperative hemoglobin (g/L) [mean (SD)] & $9.81(2.25)$ & $10.64(2.93)$ & 0.162 \\
\hline Preoperative creatinine (mg/dL) [mean (SD)] & 182.29 (109.72) & $201.78(155.62)$ & 0.583 \\
\hline Preoperative lactates (mg/dL) [mean (SD)] & $5.57(4.19)$ & $5.31(4.42)$ & 0.796 \\
\hline Preoperative $\mathrm{pH}$ [mean (SD)] & $7.27(0.16)$ & $7.25(0.15)$ & 0.524 \\
\hline Protrombin ratio (\% of normal) [mean (SD)] & $73(15.36)$ & 71.59 (10.58) & 0.520 \\
\hline Diabetes $[n(\%)]$ & $6(17.6)$ & $10(16.7)$ & 1 \\
\hline Severe coronary disease $[n(\%)]$ & $26(76.5)$ & $44(73.3)$ & 0.809 \\
\hline Previous TIA/stroke $[n(\%)]$ & $1(2.9)$ & $7(11.7)$ & 0.251 \\
\hline Hypertension [n (\%)] & $29(85.3)$ & $37(61.7)$ & 0.019 \\
\hline COPD $[n(\%)]$ & $10(29.4)$ & $10(16.7)$ & 0.191 \\
\hline Smoking $[n(\%)]$ & $15(44.1)$ & $15(25)$ & 0.068 \\
\hline Kidney failure [n (\%)] & $9(26.5)$ & $15(25)$ & 1 \\
\hline Previous carotid surgery [n (\%)] & $1(2.9)$ & $5(8.3)$ & 0.413 \\
\hline Previous aortic stenting $[n(\%)]$ & $8(23.5)$ & $6(10)$ & 0.129 \\
\hline Previous legs vascular surgery $[n(\%)]$ & $4(11.8)$ & $8(13.3)$ & 1 \\
\hline Previous colectomy [n (\%)] & $1(2.9)$ & $1(1.7)$ & 1 \\
\hline Comorbidity > $1[n(\%)]$ & $16(47.1)$ & $26(43.3)$ & 0.830 \\
\hline Cardioasa therapy $[n(\%)]$ & $5(14.7)$ & $14(23.3)$ & 0.426 \\
\hline Oral anticoagulant therapy $[n(\%)]$ & $11(32.4)$ & $13(21.7)$ & 0.326 \\
\hline Charlson Index [mean (SD)] & $5.47(2.29)$ & $5.37(2.91)$ & 0.867 \\
\hline ASA score $[n(\%)]$ & & & 0.129 \\
\hline$\|$ & $1(2.9)$ & $9(15)$ & \\
\hline III & $21(61.8)$ & $37(61.7)$ & \\
\hline N & $12(35.3)$ & $14(23.3)$ & \\
\hline Time interval from signs/symptoms onset to surgery [n(\%)] & & & 0.467 \\
\hline$<=12 \mathrm{~h}$ & $9(26.5)$ & $14(23.3)$ & \\
\hline$>12 h$ & $25(73.5)$ & $46(76.7)$ & \\
\hline Location of ischemia [n(\%)] & & & 0.015 \\
\hline Left colon & $9(26.4)$ & $10(16.6)$ & \\
\hline Right colon & $4(11.8)$ & $0(0)$ & \\
\hline Transverse & $3(8.8)$ & $3(5)$ & \\
\hline Right and transverse & $2(5.9)$ & $13(21.7)$ & \\
\hline Entire colon & $16(47.1)$ & $34(56.7)$ & \\
\hline Presence of colic perforation [ $n(\%)]$ & $6(17.6)$ & $14(23.3)$ & 0.426 \\
\hline Type of colonic resection [n (\%)] & & & 0.020 \\
\hline Hartman's resection & $9(26.5)$ & $10(16.7)$ & \\
\hline Subtotal colectomy with ileo-sigmoid colostomy & $5(14.7)$ & $16(26.7)$ & \\
\hline
\end{tabular}


Table 3 Summary of the clinical characteristics of IC patients undergoing emergency open colectomy due to aorta surgery-related IC (AS-IC group) vs. other etiologies (Other-IC group) (Continued)

\begin{tabular}{llll}
\hline Variables & AS-IC group $(n=34)$ & Other-IC group $(n=60)$ & $34(56.6)$ \\
\hline Total colectomy with terminal ileostomy & $16(47.1)$ & 0 & 0 \\
$\quad$ Right colectomy with ileo-colonostomy & $4(11.7)$ & 0 & $\mathbf{0 . 0 1 5}$ \\
Open abdomen needed $[n(\%)]$ & $4(11.8)$ & $41(68.3)$ & 0.267 \\
Preoperative vasopressor agents [n (\%)] & $19(55.9)$ & $47(78.3)$ & 0.815 \\
Intraoperative vasopressor agents $[n(\%)]$ & $27(79.4)$ &
\end{tabular}

$A S$ aortic surgery, ASA American Society of Anesthesiologist classification, BMI body mass index, COPD chronic obstructive pulmonary disease, IC ischemic colitis, TIA transient ischemic attack

Table 4 Operative and postoperative outcomes of IC patients undergoing emergency open colectomy due to aorta surgery-related IC (AS-IC group) vs. other etiologies (Other-IC group)

\begin{tabular}{|c|c|c|c|c|}
\hline Variables & $\begin{array}{l}\text { AS-IC group }(n \\
=34)\end{array}$ & $\begin{array}{l}\text { Other-IC group }(n \\
=60)\end{array}$ & $\begin{array}{l}P \\
\text { value }\end{array}$ & Adjusted $p$ value ${ }^{\#}$ \\
\hline Operative time, min [mean (SD)] & $147.67(47.68)$ & $153.82(59.71)$ & 0.632 & 0.754 \\
\hline Estimated blood loss, mL [median (range)] & $450(100-890)$ & $460(40-1000)$ & 0.178 & 0.102 \\
\hline Transfused patients [n (\%)] & $19(55.9)$ & $31(51.7)$ & 0.830 & 0.352 \\
\hline Postoperative MOF [n (\%)] & $19(55.9)$ & $37(61.7)$ & 0.664 & 0.292 \\
\hline Postoperative kidney failure [n (\%)] & $20(58.1)$ & $31(51.7)$ & 0.526 & 0.382 \\
\hline Postoperative liver failure [n(\%)] & $1(2.9)$ & $4(6.7)$ & 0.650 & 0.998 \\
\hline Postoperative heart attack [n (\%)] & $4(11.8)$ & $4(6.7)$ & 0.454 & 0.358 \\
\hline Postoperative metabolic acidosis [n (\%)] & 0 & $1(1.7)$ & 1 & 0.997 \\
\hline Postoperative respiratory failure $[n(\%)]$ & $7(20.6)$ & $7(11.7)$ & 0.366 & 0.419 \\
\hline Postoperative low output syndrome [n (\%)] & $1(2.9)$ & $4(6.7)$ & 0.650 & 0.440 \\
\hline $\begin{array}{l}\text { Postoperative complications (Clavien-Dindo Classification) [n } \\
(\%)]\end{array}$ & & & 1 & 0.307 \\
\hline III/IV & $10(29.4)$ & $18(30)$ & & \\
\hline V & $24(70.6)$ & $42(70)$ & & \\
\hline Patients in ICU [n (\%)] & $34(100)$ & $60(100)$ & 1 & NA \\
\hline Duration of ICU stay, days [mean (SD)] & $19.06(21.23)$ & $11.92(13.93)$ & 0.085 & $\begin{array}{l}0.003 \text { [adjusted mean difference } \\
12.09(3.98) \text { ] }\end{array}$ \\
\hline Hospital stay, days [mean (SD)] & $22.20(23.31)$ & $16.03(19.16)$ & 0.169 & $\begin{array}{l}0.016 \text { [adjusted mean difference } \\
12.14(4.96)]\end{array}$ \\
\hline Postoperative mortality at 90 days $[n(\%)]$ & $24(70.6)$ & $42(70)$ & 1 & 0.428 \\
\hline Survival at 1 year [n (\%)] & $9(90)$ & $17(89.5)$ & 1 & 0.999 \\
\hline Disposition* $[n(\%)]$ & & & 0.895 & 0.790 \\
\hline Home & $4(40)$ & $7(38.9)$ & & \\
\hline Rehabilitation hospital/elderly house & $6(60)$ & $11(61.1)$ & & \\
\hline $\begin{array}{l}\text { Restoration of intestinal continuity at } 1 \text { year after surgery** }[n \\
(\%)]\end{array}$ & $2(22.2)$ & $10(58.8)$ & 0.110 & 0.05 \\
\hline $\begin{array}{l}\text { Mortality after restoration of intestinal continuity at } 1 \text { year after } \\
\text { surgery }[n(\%)]\end{array}$ & 0 & 0 & NA & NA \\
\hline
\end{tabular}

MOF multi-organ failure, ICU intensive care unit

${ }^{*} n=28$

${ }^{* *} n=26$

${ }^{\#}$ Model adjusted on demographic and clinical variables significantly different between AS-IC and Other-IC groups: hypertension, localization of ischemia, type of colonic resection, and use of open abdomen 
Table 5 Factors associated with postoperative mortality

\begin{tabular}{|c|c|c|c|c|c|}
\hline \multirow[t]{2}{*}{ Variables } & \multicolumn{3}{|l|}{ Univariate analysis } & \multicolumn{2}{|l|}{ Multivariate analysis } \\
\hline & $\begin{array}{l}\text { In-hospital postoperative } \\
\text { mortality }\end{array}$ & $\begin{array}{l}\text { Odds ratio } \\
(95 \% \mathrm{Cl})\end{array}$ & $p$ value & $\begin{array}{l}\text { Adjusted odds ratio } \\
(95 \% \mathrm{Cl})\end{array}$ & $p$ value \\
\hline Age $>75$ years $[n(\%)]$ & $27(79.4)$ & $2.23(0.83-5.96)$ & 0.163 & & \\
\hline Age $>80$ years $[n(\%)]$ & $14(77.8)$ & $1.71(0.51-5.75)$ & 0.571 & & \\
\hline Age, years (per unit increase) & NA & $1.02(0.99-1.06)$ & 0.098 & $1.03(0.98-1.09)$ & 0.157 \\
\hline Female $[n(\%)]$ & $44(71)$ & $1.28(0.51-3.18)$ & 0.641 & & \\
\hline ASA score > III [n (\%)] & $21(80.8)$ & $2.29(0.76-6.84)$ & 0.211 & & \\
\hline Pancolic ischemia [n (\%)] & $35(70)$ & $1.08(0.45-2.61)$ & 1 & & \\
\hline Obesity $[n(\%)]$ & $7(63.6)$ & $1.32(0.35-4.92)$ & 0.733 & & \\
\hline BMI (per unit increase) & NA & $1.01(0.92-1.12)$ & 0.696 & & \\
\hline Hypoalbuminemia (<3.5 g/dL) [n (\%)] & $4(80)$ & $1.83(0.19-17.18)$ & 1 & & \\
\hline Lactates > $2.5 \mathrm{mmol} / \mathrm{L}[\mathrm{n}(\%)]$ & $56(76.7)$ & $\begin{array}{l}4.39(1.58- \\
12.18)\end{array}$ & 0.006 & $11.85(1.64-85.17)$ & 0.014 \\
\hline Preoperative hemoglobin level (per unit increase) & NA & $1(0.83-1.20)$ & 0.973 & & \\
\hline Diabetes $[n(\%)]$ & $56(71.8)$ & $1.98(0.65-5.97)$ & 0.244 & & \\
\hline Severe coronary disease $[n(\%)]$ & $50(71.4)$ & $1.5(0.56-3.97)$ & 0.449 & & \\
\hline COPD $[n(\%)]$ & $50(67.6)$ & $1.44(0.47-4.54)$ & 0.596 & & \\
\hline Kidney failure $[n(\%)]$ & $47(67.1)$ & $1.47(0.51-4.34)$ & 0.611 & & \\
\hline Hypertension [n (\%)] & $17(60.7)$ & $1.72(0.68-4.38)$ & 0.329 & & \\
\hline Smoking $[n(\%)]$ & $43(67.2)$ & $1.35(0.51-3.57)$ & 0.636 & & \\
\hline Comorbidity > $1[n(\%)]$ & $33(78.6)$ & $2.29(0.90-5.78)$ & 0.115 & $1.81(0.33-9.9)$ & 0.490 \\
\hline $\begin{array}{l}\text { Time from signs/symptoms onset to surgery }>12 \mathrm{~h} \\
{[n(\%)]}\end{array}$ & $60(84.5)$ & $\begin{array}{l}19.63(6.02- \\
63.97)\end{array}$ & $\begin{array}{l}< \\
0.0001\end{array}$ & $34.99(7.14-171.33)$ & $<0.0001$ \\
\hline Presence of aneurysmatic rupture* $[n(\%)]$ & $8(61.5)$ & $2(0.44-9)$ & 0.451 & & \\
\hline EVAR surgery* $[n(\%)]$ & $4(44.4)$ & $0.2(0.038-1.03)$ & 0.085 & & \\
\hline $\operatorname{AS}[n(\%)]$ & $24(70.6)$ & $1.11(0.44-2.78)$ & 1 & & \\
\hline Total colectomy $[n(\%)]$ & $35(70)$ & $1.08(0.45-2.61)$ & 1 & & \\
\hline Preoperative vasopressor agents $[n(\%)]$ & $47(78.3)$ & $3.21(1.29-8)$ & 0.019 & $2.54(0.20-31.12)$ & 0.466 \\
\hline Intraoperative vasopressor agents [n (\%)] & $55(74.3)$ & $2.89(1.04-8)$ & 0.037 & $6.37(0.87-46.6)$ & 0.068 \\
\hline Sepsis $[n(\%)]$ & $32(84.2)$ & $\begin{array}{l}3.71(1.33- \\
10.32)\end{array}$ & 0.012 & $2.31(0.61-8.79)$ & 0.218 \\
\hline Low output syndrome [n (\%)] & $5(100)$ & $1.48(1.28-1.71)$ & 0.125 & $3.83(0.3-48.97)$ & 0.301 \\
\hline Postoperative acute kidney injury [n (\%)] & $39(76.5)$ & $2.12(0.87-5.17)$ & 0.118 & $5.09(1.13-22.8)$ & 0.033 \\
\hline Operative time, min (per unit increase) & NA & $1(0.99-1.01)$ & 0.493 & & \\
\hline Blood loss > $500 \mathrm{~mL}[n(\%)]$ & 45 (78.9) & $3.18(1.28-7.89)$ & 0.013 & $2.48(0.68-9.05)$ & 0.169 \\
\hline Open abdomen needed [n (\%)] & $4(100)$ & $1.47(1.27-1.7)$ & 0.172 & $0(0-0)$ & 0.999 \\
\hline ICMR score (per unit increase) & NA & $1.37(0.89-2.12)$ & 0.146 & $2.85(0.91-8.91)$ & 0.072 \\
\hline
\end{tabular}

ASA American Society of Anesthesiologists, AS for aortic surgery, COPD for chronic obstructive pulmonary disease, EVAR endovascular aortic repair, ICMR Ischemic Colitis Mortality Risk

${ }^{*} n=34$

the severity of comorbid diseases in AS-IC patients. Indeed, these patients showed most of the time cardiovascular comorbidities, which have detrimental effects on disease evolution and may be related to worse postoperative outcomes. In the study by Castleberry et al. [34], $24 \%$ of IC survivors underwent elective end-ostomy reversal with a mortality rate of $18 \%$. Mariani et al. [41] described good outcomes after the restoration of intestinal continuity following colectomy for IC. This was possible in $40 \%$ of survivors, and the median delay between colectomy and the intestinal continuity restoration was 7.9 months (range $0.2-35$ months). There was no postoperative mortality, but $13 \%$ developed surgical complications (e.g., lower digestive tract bleeding, wound 
Table 6 Summary of the most relevant studies in the literature on IC-related mortality following emergency colectomy

\begin{tabular}{|c|c|c|c|c|c|c|c|c|c|c|}
\hline Author, year & Study design & $\begin{array}{l}\text { Study } \\
\text { time } \\
\text { frame }\end{array}$ & Number & $\begin{array}{l}\text { Mean or } \\
\text { median } \\
\text { age } \\
\text { (years) }\end{array}$ & IC etiology & IC localization & $\begin{array}{l}\text { IC requiring } \\
\text { surgery (by } \\
\text { procedure) }\end{array}$ & $\begin{array}{l}\text { IC } \\
\text { mortality }\end{array}$ & $\begin{array}{l}\text { Risk factors for IC } \\
\text { mortality }\end{array}$ & Survival \\
\hline $\begin{array}{l}\text { Aday et al., } \\
2018\end{array}$ & $\begin{array}{l}\text { Retrospective } \\
\text { single-center } \\
\text { study }\end{array}$ & $\begin{array}{l}2012- \\
2016\end{array}$ & 275 & 62 & $\begin{array}{l}\text { Cardiovascular } \\
\text { surgery }\end{array}$ & NA & $\begin{array}{l}\text { Overall, 5\% } \\
\text { EVAR, 28.5\% } \\
\text { open } \\
\text { surgery, } \\
71.5 \%\end{array}$ & $\begin{array}{l}\text { nrAAA, } \\
62.5 \% \\
\text { rAAA, } \\
83 \%\end{array}$ & NA & NA \\
\hline $\begin{array}{l}\text { Gilshtein } \\
\text { et al., } 2018\end{array}$ & $\begin{array}{l}\text { Retrospective } \\
\text { single-center } \\
\text { study }\end{array}$ & $\begin{array}{l}2011- \\
2016\end{array}$ & 63 & 72.5 & NA & NA & Overall, 19\% & $50 \%$ & $\begin{array}{l}\text { - Older age } \\
\text { - Comorbidities } \\
\text { (chronic renal } \\
\text { disease, ischemic } \\
\text { heart disease) } \\
\text { - Higher lactate level }\end{array}$ & NA \\
\hline $\begin{array}{l}\text { Noh et al., } \\
2015\end{array}$ & $\begin{array}{l}\text { Retrospective } \\
\text { single-center } \\
\text { study }\end{array}$ & $\begin{array}{l}2003- \\
2011\end{array}$ & 50 & 68 & Medical causes & $\begin{array}{l}\text { Right colon, } \\
22 \% \\
\text { Left colon, } \\
66 \% \\
\text { Transverse } \\
\text { colon, 6\% } \\
\text { Pancolic, 6\% }\end{array}$ & $100 \%$ & $30 \%$ & $\begin{array}{l}\text { - History of } \\
\text { cardiovascular } \\
\text { surgery } \\
\text { - Delay to surgery } \geq \\
3 \text { days }\end{array}$ & NA \\
\hline $\begin{array}{l}\text { Genstorfer } \\
\text { et al., } 2014\end{array}$ & $\begin{array}{l}\text { Retrospective } \\
\text { single-center } \\
\text { study }\end{array}$ & $\begin{array}{l}2004- \\
2010\end{array}$ & 100 & 74 & $\begin{array}{l}\text { Aortic surgery, } \\
16 \% \\
\text { Cardiac } \\
\text { surgery, } 17 \%\end{array}$ & $\begin{array}{l}\text { Right colon, } \\
\text { 33\% Left } \\
\text { colon, 40\% } \\
\text { Pancolic, 27\% }\end{array}$ & $100 \%$ & $54 \%$ & $\begin{array}{l}\text { - Right colon } \\
\text { ischemia } \\
\text { - Pancolic ischemia } \\
\text { - Decrease } \\
\text { preoperative pH } \\
\text { - Prior cardiac/aortic } \\
\text { surgery }\end{array}$ & NA \\
\hline $\begin{array}{l}\text { Moszkowicz } \\
\text { et al., } 2014\end{array}$ & $\begin{array}{l}\text { Retrospective } \\
\text { single-center } \\
\text { study }\end{array}$ & $\begin{array}{l}1997- \\
2012\end{array}$ & 191 & 70 & $\begin{array}{l}\text { Aortic surgery, } \\
62 \% \\
\text { Spontaneous, } \\
38 \%\end{array}$ & $\begin{array}{l}\text { AS-IC: } \\
\text { Right colon, } \\
2 \% \\
\text { Left colon, } \\
45 \% \\
\text { Pancolic, 53\% } \\
\text { Spontaneous } \\
\text { IC: } \\
\text { Right colon, } \\
60 \% \\
\text { Left colon, } \\
13 \% \\
\text { Pancolic, 6\% }\end{array}$ & $91 \%$ & $48 \%$ & $\begin{array}{l}\text { - Age older than } 75 \\
\text { years } \\
\text { - Multiple organ } \\
\text { failure }\end{array}$ & NA \\
\hline $\begin{array}{l}\text { Castleberry } \\
\text { et al., } 2013\end{array}$ & $\begin{array}{l}\text { Retrospective } \\
\text { single-center } \\
\text { study }\end{array}$ & $\begin{array}{l}2000- \\
2009\end{array}$ & 115 & 64 & $\begin{array}{l}\text { Gl surgery, } \\
12 \% \\
\text { Cardiovascular } \\
\text { surgery, } 26 \%\end{array}$ & $\begin{array}{l}\text { Right colon, } \\
49 \% \\
\text { Pancolic, 26\% }\end{array}$ & $100 \%$ & $\begin{array}{l}\text { In } \\
\text { hospital, } \\
37 \%\end{array}$ & $\begin{array}{l}\text { - ASA > } 4 \\
\text { - Preoperative lactate } \\
\text { level } \\
\text { - Renal failure } \\
\text { requiring } \\
\text { hemodialysis } \\
\text { - Intraoperative } \\
\text { adrenergic } \\
\text { vasopressor use } \\
\text { - Blood loss > 500 } \\
\text { mL }\end{array}$ & $\begin{array}{l}1 \text { year, } \\
43 \% \\
3 \text { years, } \\
33 \% \\
5 \text { years, } \\
27 \%\end{array}$ \\
\hline $\begin{array}{l}\text { Reissfelder } \\
\text { et al., } 2011\end{array}$ & $\begin{array}{l}\text { Retrospective } \\
\text { single-center } \\
\text { study }\end{array}$ & $\begin{array}{l}2002- \\
2008\end{array}$ & 177 & 69 & NA & NA & $100 \%$ & $48 \%$ & $\begin{array}{l}\text { - Non-occlusive IC } \\
\text { - Acute renal failure } \\
\text { - Extent of bowel } \\
\text { ischemia } \\
\text { - Lactate level } \\
\text { - Duration of } \\
\text { catecholamine } \\
\text { therapy }\end{array}$ & NA \\
\hline $\begin{array}{l}\text { Antolovic } \\
\text { et al., } 2008\end{array}$ & $\begin{array}{l}\text { Retrospective } \\
\text { single-center } \\
\text { study }\end{array}$ & $\begin{array}{l}2001- \\
2004\end{array}$ & 85 & 68.5 & $\begin{array}{l}\text { Cardiovascular } \\
\text { surgery, } 55 \%\end{array}$ & $\begin{array}{l}\text { Right colon, } \\
26 \% \\
\text { Left colon, }\end{array}$ & $100 \%$ & $47 \%$ & $\begin{array}{l}\text { - ASA >3 } \\
\text { - Emergency surgery } \\
\text { - Blood loss }\end{array}$ & NA \\
\hline
\end{tabular}


Table 6 Summary of the most relevant studies in the literature on IC-related mortality following emergency colectomy (Continued)

\begin{tabular}{|c|c|c|c|c|c|c|c|c|c|c|}
\hline Author, year & Study design & $\begin{array}{l}\text { Study } \\
\text { time } \\
\text { frame }\end{array}$ & Number & $\begin{array}{l}\text { Mean or } \\
\text { median } \\
\text { age } \\
\text { (years) }\end{array}$ & IC etiology & IC localization & $\begin{array}{l}\text { IC requiring } \\
\text { surgery (by } \\
\text { procedure) }\end{array}$ & $\begin{array}{l}\text { IC } \\
\text { mortality }\end{array}$ & $\begin{array}{l}\text { Risk factors for IC } \\
\text { mortality }\end{array}$ & Survival \\
\hline & & & & & & $\begin{array}{l}\text { Sigmoid, 5\% } \\
\text { Pancolic, 49\% }\end{array}$ & & & & \\
\hline $\begin{array}{l}\text { Huguier } \\
\text { et al., } 2006\end{array}$ & $\begin{array}{l}\text { Retrospective } \\
\text { single-center } \\
\text { study }\end{array}$ & $\begin{array}{l}1992- \\
1999\end{array}$ & 73 & 73 & NA & Pancolic, 9\% & $45 \%$ & $62 \%$ & $\begin{array}{l}\text { - Age }<80 \text { years } \\
\text { - Male gender } \\
\text { - Absence of } \\
\text { bleeding } \\
\text { - Abdominal } \\
\text { tenderness }\end{array}$ & $\begin{array}{l}2 \text { years, } \\
88 \% \\
5 \text { years, } \\
68 \%\end{array}$ \\
\hline $\begin{array}{l}\text { Present } \\
\text { study }\end{array}$ & $\begin{array}{l}\text { Retrospective } \\
\text { single-center } \\
\text { study }\end{array}$ & $\begin{array}{l}2008- \\
2019\end{array}$ & 94 & 72 & $\begin{array}{l}\text { Aortic surgery, } \\
36.2 \% \\
\text { Other causes, } \\
63.8 \%\end{array}$ & $\begin{array}{l}\text { Right colon, } \\
4.3 \% \\
\text { Left colon, } \\
20.2 \% \\
\text { Transverse } \\
\text { colon, } 6.4 \% \\
\text { Pancolic, } \\
53.2 \%\end{array}$ & $\begin{array}{l}\text { Overall, } \\
100 \% \\
\text { EVAR, 26.\% } \\
\text { Open } \\
\text { surgery, } \\
73.5 \% \\
\text { rAAA, 61.8\% }\end{array}$ & $\begin{array}{l}\text { In } \\
\text { hospital/ } \\
90 \text { days, } \\
70.2 \%\end{array}$ & $\begin{array}{l}\text { - Preoperative } \\
\text { lactates level } \\
\text { - Time interval from } \\
\text { symptoms onset to } \\
\text { surgery } \\
\text { - Intraoperatory } \\
\text { adrenergic } \\
\text { vasopressors } \\
\text { - Postoperative } \\
\text { kidney failure } \\
\text { - ICMR score }\end{array}$ & $\begin{array}{l}1 \text { year, } \\
27.6 \%\end{array}$ \\
\hline
\end{tabular}

IC ischemic colitis, AAA aortic abdominal repair, AFib/RVR Atrial fibrillation with rapid ventricular response, EVAR endovascular aortic repair, GI gastrointestinal, IMA inferior mesenteric artery, $n r A A A$ non-ruptured AAA, $r A A A$ ruptured AAA, RCI right colonic ischemia, SMA superior mesenteric artery

infection) and 33\% medical complications (e.g., pneumonia, cardiac failure, acute renal failure) [41]. The authors did not find any clinical or biological discriminant factor that may help in identifying which patients should undergo reversal surgery. However, they supported that the restorati0on of intestinal continuity should be discussed in multidisciplinary meeting for every surviving IC patient, and although challenging, it should be considered to improve quality of life in selected, motivated patients [41]. In the same vein, further studies may explore the possibility to manage IC by emergency laparoscopy to obtain additional advantages in the postoperative period related to the minimally invasive approach [42, 43]. However, this may be conceivable only in highly selected patients, depending on the IC severity and etiology (nonrelated to aorta surgery).

The present study has limitations that must be considered when interpreting the results. It is a retrospective analysis of an 11-year cohort of IC patients requiring emergency surgery. Patients were treated in a single institution over a long period of time; although the health database was prospectively maintained, reporting and selection bias cannot be ruled out. Furthermore, the external validity of the findings is limited. However, the present study investigated a relatively large sample of IC patients all treated by open colectomy in an emergency setting. Studies in the literature are rather heterogeneous in methods and target populations, making direct comparisons difficult. Efforts should be made in future studies, both prospective and retrospective, to standardize outcome measures and preoperative evaluation, in order to facilitate study comparisons as well as a comprehensive appraisal of the body of literature.

\section{Conclusions}

Emergency open colectomy for IC is associated with high postoperative mortality. The levels of preoperative lactates, a delay to surgery $>12 \mathrm{~h}$, and the occurrence of postoperative acute kidney injury are found to be independent predictors of postoperative mortality. The specific etiology of IC, namely aortic surgery complications or other causes, appears to have no impact on postoperative mortality. These results support the key role of prompt diagnosis and surgical intervention in the management of severe IC. Moreover, the present data indicate that survivors in the Other-IC group are more likely to undergo intestinal continuity restoration within 1 year from IC surgery compared to AS-IC patients, which may have a considerable impact on IC survivors' quality of life.

\section{Abbreviations}

AAA: Abdominal aortic aneurism; AS: Aortic surgery; ASA: American Society of Anesthesiologist classification; BMI: Body mass index; COPD: Chronic obstructive pulmonary disease; EVAR: Endovascular aneurysm repair; IC: Ischemic colitis; ICU: Intensive care unit; MOF: Multi-organ failure

\section{Acknowledgements}

Nil

\section{Authors' contributions}

NdeA and FB contributed to the concept of the study design, data analyses and interpretation, and manuscript critical revision. ER and NB contributed to the data collection, literature search, data interpretation, and manuscript drafting. FC-P, MN, and DS contributed to the statistical analysis and data interpretation. FC, PD, ALu, ALa, AA, SM, NM, MN, LL, OL, and IS contributed to 
the literature critical review, data interpretation, and manuscript critical revision. All authors read and approved the final version of the manuscript.

\section{Funding}

No specific funding was received for this work.

\section{Availability of data and materials}

The authors are responsible for the data described in the manuscript and assure full availability of the study material.

\section{Ethics approval and consent to participate}

The study protocol was approved by the Institutional Review Board (IRB: 00011558) and was conducted in conformity to the principles declared to the National Commission for Data Protection and Liberties (CNIL: 2210699) and in accordance with the ethical principles described in the Declaration of Helsinki. Consent to participate is not applicable.

\section{Consent for publication}

Not applicable

\section{Competing interests}

The authors declare to have no competing interest to disclose in relation to the present study.

\section{Author details}

${ }^{1}$ Unit of Digestive and HPB surgery, CARE Department, Henri Mondor Hospital, AP-HP, and Université Paris Est, UPEC, 51 Avenue du Maréchal de Lattre de Tassigny, 94010 Créteil, France. ${ }^{2}$ Unit of vascular surgery, CARE Department, Henri Mondor Hospital, AP-HP, and Université Paris Est, UPEC, Créteil, France. ${ }^{3}$ Department of Gastroenterology and Digestive Endoscopy, Henri Mondor Hospital, AP-HP, and Université Paris Est, UPEC, Créteil, France. ${ }^{4}$ Service d'anesthésie-réanimation chirurgicale, DMU CARE, DHU A-TVB, Assistance Publique-Hôpitaux de Paris (AP-HP), Hôpitaux Universitaires Henri Mondor, 94010 Créteil, France. ${ }^{5}$ Université Paris Est Creteil, Faculté de Santé, 94010 Créteil, France. ${ }^{6}$ Unit of Radiology, Henri Mondor Hospital, AP-HP, and Université Paris Est, UPEC, Créteil, France. IInserm U955, Team 18, Créteil, France. ${ }^{8}$ Clinical Epidemiology and Ageing Unit, Henri Mondor Hospital, APHP, EA 7376, CEpiA-IMRB, Université Paris Est, Créteil, France.

\section{Received: 19 May 2020 Accepted: 17 June 2020}

Published online: 29 June 2020

\section{References}

1. Demetriou G, Nassar A, Subramonia S. The pathophysiology, presentation and management of ischaemic colitis: a systematic review. World J Surg. 2020;44(3):927-38.

2. Diaz Nieto R. M. Varcada, O.A. Ogunbiyi, and M.C. Winslet, Systematic review on the treatment of ischaemic colitis. Colorectal Dis. 2011;13(7):744-7.

3. Moszkowicz D, Tresallet C, Mariani A, et al. Ischaemic colitis: indications, extent, and results of standardized emergency surgery. Dig Liver Dis. 2014; 46(6):505-11.

4. Washington C, Carmichael JC. Management of ischemic colitis. Clin Colon Rectal Surg. 2012;25(4):228-35.

5. Brandt L, Feuerstadt P, Longstreth GF, Boley SJ, American College G. of, ACG clinical guideline: epidemiology, risk factors, patterns of presentation, diagnosis, and management of colon ischemia (Cl). Am J Gastroenterol. 2015;110(1):18-44 quiz 5

6. Choi SR, Jee SR, Song GA, et al. Predictive factors for severe outcomes in ischemic colitis. Gut Liver. 2015:9(6):761-6.

7. O'Neill S, Yalamarthi S. Systematic review of the management of ischaemic colitis. Colorectal Dis. 2012;14(11):e751-63.

8. Paterno F, McGillicuddy EA, Schuster KM, Longo WE. Ischemic colitis: risk factors for eventual surgery. Am J Surg. 2010;200(5):646-50.

9. Sotiriadis J, Brandt LJ, Behin DS, Southern WN. Ischemic colitis has a worse prognosis when isolated to the right side of the colon. Am J Gastroenterol. 2007:102(10):2247-52.

10. Tadros M, Majumder S, Birk JW. A review of ischemic colitis: is our clinical recognition and management adequate? Expert Rev Gastroenterol Hepatol. 2013;7(7):605-13.

11. FitzGerald JF, Hernandez lii LO. Ischemic colitis. Clin Colon Rectal Surg. 2015; 28(2):93-8.
12. Theodoropoulou A, Koutroubakis IE. Ischemic colitis: clinical practice in diagnosis and treatment. World J Gastroenterol. 2008;14(48):7302-8.

13. Moszkowicz D, Mariani A, Tresallet C, Menegaux F. Ischemic colitis: the ABCs of diagnosis and surgical management. J Visc Surg. 2013;150(1):19-28.

14. Lee MJ, Daniels SL, Drake TM, Adam IJ. Risk factors for ischaemic colitis after surgery for abdominal aortic aneurysm: a systematic review and observational meta-analysis. Int J Colorectal Dis. 2016;31(7):1273-81.

15. Moghadamyeghaneh Z, Sgroi MD, Chen SL, et al. Risk factors and outcomes of postoperative ischemic colitis in contemporary open and endovascular abdominal aortic aneurysm repair. J Vasc Surg. 2016;63(4):866-72.

16. Aday U, Gundes E, Cetin DA, et al. Ischemic colitis following infrarenal abdominal aortic aneurysm treatment: results from a tertiary medical center. North Clin Istanb. 2018:5(3):221-6.

17. Becquemin JP, Majewski M, Fermani N, et al. Colon ischemia following abdominal aortic aneurysm repair in the era of endovascular abdominal aortic repair. J Vasc Surg. 2008;47(2):258-63 discussion 63.

18. Desikan SK, Singh N, Steele SR, et al. The incidence of ischemic colitis after repair of ruptured abdominal aortic aneurysms is decreasing in the endovascular era. Ann Vasc Surg. 2018;47:247-52.

19. Sun D, Wang C, Yang L, Liu M, Chen F. The predictors of the severity of ischaemic colitis: a systematic review of 2823 patients from 22 studies. Colorectal Dis. 2016;18(10):949-58.

20. Genstorfer J, Schafer J, Kettelhack C, Oertli D, Rosenthal R. Surgery for ischemic colitis: outcome and risk factors for in-hospital mortality. Int J Colorectal Dis. 2014;29(4):493-503.

21. Champagne BJ, Darling RC 3rd, Daneshmand M, et al. Outcome of aggressive surveillance colonoscopy in ruptured abdominal aortic aneurysm. J Vasc Surg. 2004;39(4):792-6.

22. Williamson JS, Ambler GK, Twine CP, Williams IM, Williams GL. Elective repair of abdominal aortic aneurysm and the risk of colonic ischaemia: systematic review and meta-analysis. Eur J Vasc Endovasc Surg. 2018;56(1):31-9.

23. Ghosh J, Khwaja N, Howarth V, et al. Colonic epithelial apoptosis during conventional and endoluminal aortic surgery. Br J Surg. 2005;92(4):443-8.

24. Gilshtein H, Hallon K, Kluger Y. Ischemic colitis caused increased early and delayed mortality. World J Emerg Surg. 2018;13:31.

25. Glauser PM, Wermuth P, Cathomas G, et al. Ischemic colitis: clinical presentation, localization in relation to risk factors, and long-term results. World J Surg. 2011:35(11):2549-54.

26. Antolovic $D$, Koch $M$, Hinz $U$, et al. Ischemic colitis: analysis of risk factors for postoperative mortality. Langenbecks Arch Surg. 2008;393(4):507-12.

27. Arif $R$, Farag $M$, Zaradzki $M$, et al. Ischemic colitis after cardiac surgery: can we foresee the threat? PLoS One. 2016;11(12):e0167601.

28. Plastaras L, Vuitton L, Badet N, et al. Acute colitis: differential diagnosis using multidetector CT. Clin Radiol. 2015;70(3):262-9.

29. Copin P, Zins M, Nuzzo A, et al. Acute mesenteric ischemia: a critical role for the radiologist. Diagn Interv Imaging. 2018;99(3):123-34.

30. Favier C, Bonneau HP, Tran Minh V, Devic J. Endoscopic diagnosis of regressive ischemic colitis. Endoscopic, histologic and arteriographic correlations. Nouv Presse Med. 1976:5(2):77-9.

31. Reissfelder C, Sweiti $H$, Antolovic D, et al. Ischemic colitis: who will survive? Surgery. 2011;149(4):585-92.

32. Kidney Disease: Improving Global, O., KDIGO clinical practice guidelines for the prevention, diagnosis, evaluation, and treatment of hepatitis $C$ in chronic kidney disease. Kidney Int Suppl. 2008(109): S1-99.

33. Dindo D, Demartines N, Clavien PA. Classification of surgical complications: a new proposal with evaluation in a cohort of 6336 patients and results of a survey. Ann Surg. 2004;240(2):205-13.

34. Castleberry AW, Turley RS, Hanna JM, et al. A 10-year longitudinal analysis of surgical management for acute ischemic colitis. J Gastrointest Surg. 2013; 17(4):784-92.

35. Chung JW, Cheon JH, Park JJ, et al. Development and validation of a novel prognostic scoring model for ischemic colitis. Dis Colon Rectum. 2010;53(9):1287-94.

36. Noh M, Yang SS, Jung SW, et al. Poor prognostic factors in patients who underwent surgery for acute non-occlusive ischemic colitis. World J Emerg Surg. 2015;10:12

37. Ritz JP, Germer $\subset$, Buhr HJ. Prognostic factors for mesenteric infarction: multivariate analysis of 187 patients with regard to patient age. Ann Vasc Surg. 2005;19(3):328-34.

38. Cremone C, Esch A, Gagniere C, et al. Patients' comorbidities reduce the clinical value of emergency colonoscopy: results of a retrospective cohort study. Endosc Int Open. 2017;5(11):E1119-E27. 
39. Longo WE, Ward D, Vernava AM 3rd, Kaminski DL. Outcome of patients with total colonic ischemia. Dis Colon Rectum. 1997;40(12):1448-54.

40. Behrendt CA, Riess HC, Schwaneberg T, et al. Incidence, predictors, and outcomes of colonic ischaemia in abdominal aortic aneurysm repair. Eur J Vasc Endovasc Surg. 2018;56(4):507-13.

41. Mariani A, Moszkowicz D, Tresallet C, et al. Restoration of intestinal continuity after colectomy for non-occlusive ischemic colitis. Tech Coloproctol. 2014;18(7):623-7.

42. Keller DS, Pedraza R, Flores-Gonzalez JR, et al. The current status of emergent laparoscopic colectomy: a population-based study of clinical and financial outcomes. Surg Endosc. 2016;30(8):3321-6.

43. Watanabe K, Funayama Y, Fukushima K, et al. Hand-assisted laparoscopic vs. open subtotal colectomy for severe ulcerative colitis. Dis Colon Rectum. 2009;52(4):640-5.

\section{Publisher's Note}

Springer Nature remains neutral with regard to jurisdictional claims in published maps and institutional affiliations.

Ready to submit your research? Choose BMC and benefit from:

- fast, convenient online submission

- thorough peer review by experienced researchers in your field

- rapid publication on acceptance

- support for research data, including large and complex data types

- gold Open Access which fosters wider collaboration and increased citations

- maximum visibility for your research: over $100 \mathrm{M}$ website views per year

At $\mathrm{BMC}$, research is always in progress.

Learn more biomedcentral.com/submissions 